\title{
57. CHEMICAL COMPOSITION AND METAL ACCUMULATION RATES OF JAPAN TRENCH INNER SLOPE SEDIMENTS, LEG 57, DEEP SEA DRILLING PROJECT
}

\author{
Masato Nohara, Department of Marine Geology, Geological Survey of Japan, Tsukuba, Ibaraki, Japan
}

\section{INTRODUCTION}

Several papers have recently appeared concerning the metalliferous sediments on the active oceanic ridges. The geochemistry of such sediments is reasonably well understood and the deposits generally considered to be products of volcanic processes (Boström and Peterson, 1969; Boström et al., 1969; Horowitz, 1970, 1974; Cronan et al., 1972; Cronan and Garrett, 1973; Piper, 1973). The geochemistry of trench sediments, however, is less well known. There is a great need for studies of trench inner slope sediments, particularly in view of the significance of such sediments as a record of the effects of oceanic plate subduction under the continental crust. Sampling by Glomar Challenger in the trench inner slope was therefore of utmost importance in determining the origin of trench inner slope deposits.

\section{ANALYTICAL METHOD}

Samples were dried at less than $35^{\circ} \mathrm{C}$. Prior to chemical analysis, the sediments were ground to a smaller than 200-mesh screen with a Retisch mortar grinder. Chemical analyses were carried out with a Perkin-Elmer 503 atomic absorption spectrophotometer after a combined $\mathrm{HF}-\mathrm{HClO}_{4}-\mathrm{HCl}$ digestion involving double fuming with $\mathrm{HF}-\mathrm{HClO}_{4}$. All determinations were done in duplicate, and the precision and accuracy of the analyses were checked by using JG-1 and JB-1 J.G.S. standards. In most cases, accuracy of concentrations of various elements in J.G.S. standard samples was in agreement within \pm 15 per cent for $\mathrm{Al}$ and $\mathrm{Ti}$ and within \pm 5 per cent for other elements.

\section{RESULTS AND DISCUSSION}

\section{Vertical Profiles of Chemical Composition in the Japan Trench Inner Slope Sediments}

The results of bulk chemical analyses for Leg 57 presented in Table 1 and Figures 1 and 2 are for untreated samples, since carbonate correction or normalizing to either $\mathrm{Al}+\mathrm{Fe}+\mathrm{Mn}, 4 \mathrm{Al}+\mathrm{Fe}+\mathrm{Mn}+\mathrm{Ti}$, or $\mathrm{Al}_{2} \mathrm{O}_{3}$, as has been suggested by various other workers (Boström and Peterson, 1969; Boström et al., 1969; Piper, 1973), does not markedly alter the distribution patterns.

\section{Site 438 (Holes 438, 438A, and 438B)}

Holes 438, 438A, and 438B at Site 438 were drilled in a fault-bounded block on a terrace in the trench inner slope. We recovered continuous hemipelagic sediment sections from the three holes ranging from the lower
Miocene to the Pleistocene. With some exceptions, the intervening middle Miocene through upper Pliocene lithology is relatively monotonous, consisting mainly of diatomaceous clay-claystone and clayey diatom oozediatomite. A substantial volcanic ash component is present in the upper 500 meters of sections, both as ash layers and as volcanic glass dispersed within the oozes and clays.

$\mathrm{Al}$ is markedly variable, ranging from 3.3 to 8.1 per cent and averaging 6.1 per cent. Its high values occur in the Pliocene-Pleistocene and the lower-middle Miocene, in which volcanic glass is abundant (5-15 per cent); ( $2-5$ per cent). It is found only in small quantities throughout the remainder of the sections. $\mathrm{Ti}$ is also high in volcanic ash layers and in disseminated volcanic glass. Its vertical variations, however, are small with respect to those of $\mathrm{Al}$. Fe concentrations vary from 1.3 to 4.8 per cent and average 2.3 per cent. In general, its values show small vertical variation, with a few exceptions. It occurs in elevated amounts in the upper and in nearbottom sections, which are the Pliocene-Pleistocene and lower-middle Miocene. Mn reveals no remarkable vertical variations either. The upper (Pleistocene) and lower (lower Miocene) parts are relatively enriched in $\mathrm{Mn}$ as well as in Fe.

Of the trace elements, $\mathrm{Cu}$ is depleted in Pleistocene and in part of the lower Pliocene sediments, and its concentrations reflect no sediment characteristics. For instance, the $\mathrm{Cu}$ concentrations in diatomaceous ooze are similar to those in volcanic ash or volcanic glass. Similarly, the geochemical profiles of $\mathrm{Zn}, \mathrm{Ni}$, and $\mathrm{Cr}$ display no continuous trend throughout the core sections, although their values reach a maximum in the lower parts. $\mathrm{Co}, \mathrm{Li}$, and $\mathrm{Sr}$ are somewhat variable compared with other trace elements. The major contributors of $\mathrm{Sr}$ to the marine sediments are the carbonate-forming coccoliths and foraminifers (Turekian, 1964). Sr concentrations, however, are low in upper Miocene sediments (593-817 m); these sediments do sometimes contain calcareous concretions and limestone, however, though these were not analyzed.

\section{Site 439}

The hole at site 439 was drilled at a depth of 1656 meters, about $35 \mathrm{~km}$ landward from the top of the Japan Trench inner slope. It is $5 \mathrm{~km}$ from site 438 and begins with the same stratigraphic sequence. The lithology of sediments is diatom-bearing claystone, interbedded sandstone-siltstone, massive friable silty sandstone, and very well indurated silty claystone. Their ages of sediments analyzed range from lower Miocene to upper Oligocene. 
TABLE 1

Analytical Results of Sediment Samples from Deep Sea Drilling Project Leg 57

\begin{tabular}{|c|c|c|c|c|c|c|c|c|c|c|c|}
\hline $\begin{array}{c}\text { Sample } \\
\text { (Interval in } \mathrm{cm} \text { ) }\end{array}$ & $\begin{array}{c}\mathrm{Al} \\
(\%)\end{array}$ & $\begin{array}{l}\mathrm{Ti} \\
(\%)\end{array}$ & $\begin{array}{l}\mathrm{Fe} \\
(\%)\end{array}$ & $\begin{array}{l}\mathrm{Mn} \\
(\mathrm{ppm})\end{array}$ & $\begin{array}{c}\mathrm{Cu} \\
(\mathrm{ppm})\end{array}$ & $\underset{(\mathrm{ppm})}{\mathrm{Zn}}$ & $\begin{array}{l}\mathrm{Ni} \\
\text { (ppm) }\end{array}$ & $\begin{array}{l}\text { Co } \\
\text { (ppm) }\end{array}$ & $\begin{array}{l}\mathrm{Cr} \\
\text { (ppm) }\end{array}$ & $\begin{array}{c}\mathrm{Li} \\
(\mathrm{ppm})\end{array}$ & $\begin{array}{c}\mathrm{Sr} \\
\text { (ppm) }\end{array}$ \\
\hline \multicolumn{12}{|l|}{ Hole 438} \\
\hline $1-2,98-102$ & 8.07 & 0.40 & 2.28 & 834 & 16 & 70 & 42 & 32 & 49 & 26 & 64 \\
\hline $3-2,60-64$ & 7.03 & 0.54 & 2.53 & 413 & 30 & 88 & 58 & 30 & 76 & 37 & 131 \\
\hline $5-4,30-34$ & 8.13 & 0.50 & 4.82 & 781 & 18 & 96 & 43 & 35 & 58 & 25 & 58 \\
\hline $7-2,60-64$ & 6.62 & 0.44 & 2.03 & 539 & 31 & 88 & 45 & 33 & 45 & 26 & 61 \\
\hline $9-2,132-136$ & 6.19 & 0.41 & 2.29 & 437 & 27 & 93 & 45 & 35 & 49 & 32 & 50 \\
\hline $10-3,100-104$ & 7.16 & 0.46 & 2.08 & 569 & 24 & 99 & 54 & 37 & 58 & 29 & 71 \\
\hline $11-2,76-80$ & 6.36 & 0.48 & 2.68 & 563 & 20 & 93 & 42 & 34 & 62 & 23 & 73 \\
\hline \multicolumn{12}{|l|}{ Hole 438A } \\
\hline $1-2,66-70$ & 7.67 & 0.54 & 3.69 & 713 & 5 & 102 & 42 & 46 & 58 & 24 & 98 \\
\hline $3-2,72-76$ & 7.90 & 0.52 & 3.61 & 711 & 2 & 93 & 46 & 40 & 52 & 25 & 72 \\
\hline $5-2,145-147$ & 6.78 & 0.36 & 1.92 & 528 & 14 & 72 & 24 & 30 & 27 & 20 & 126 \\
\hline $7-2,41-42$ & 5.17 & 0.38 & 1.94 & 405 & 26 & 96 & 50 & 23 & 55 & 41 & 72 \\
\hline $9-1,22-24$ & 3.95 & 0.35 & 2.15 & 315 & 37 & 86 & 38 & 19 & 48 & 30 & 71 \\
\hline $11-2,84-88$ & 3.33 & 0.27 & 1.43 & 272 & 13 & 76 & 40 & 10 & 41 & 26 & 67 \\
\hline $13-2,9-13$ & 3.28 & 0.40 & 1.36 & 294 & 33 & 81 & 46 & 5 & 39 & 32 & 57 \\
\hline $17-2,62-64$ & 5.94 & 0.41 & 1.99 & 388 & 51 & 108 & 56 & 15 & 56 & 55 & 37 \\
\hline $19-2,60-64$ & 4,81 & 0.34 & 1.91 & 381 & 35 & 89 & 48 & 16 & 40 & 47 & 35 \\
\hline $21-2,40-44$ & 5.56 & 0.40 & 1.90 & 358 & 36 & 101 & 51 & 16 & 46 & 55 & 34 \\
\hline $23-1,34-38$ & 5.57 & 0.35 & 1.43 & 250 & 41 & 98 & 44 & 15 & 53 & 46 & 31 \\
\hline $24-1,20-22$ & 6.65 & 0.42 & 1.98 & 313 & 34 & 114 & 42 & 23 & 67 & 55 & 24 \\
\hline $25-2,120-124$ & 6.00 & 0.38 & 1.78 & 324 & 45 & 101 & 40 & 13 & 58 & 51 & 48 \\
\hline $27-2,50-54$ & 7.51 & 0.32 & 1.74 & 258 & 42 & 99 & 37 & 9 & 41 & 44 & 40 \\
\hline $29-2$ & 3.64 & 0.26 & 1.29 & 171 & 34 & 86 & 34 & 4 & 46 & 38 & 24 \\
\hline $31-2,40-44$ & 3.30 & 0.26 & 1.39 & 230 & 30 & 93 & 31 & 6 & 43 & 38 & 83 \\
\hline $33-2,36-40$ & 4.87 & 0.36 & 2.73 & 456 & 31 & 94 & 39 & 15 & 43 & 36 & 45 \\
\hline $35-2,10-14$ & 5.29 & 0.29 & 1.62 & 446 & 30 & 95 & 41 & 26 & 41 & 36 & 34 \\
\hline $37-2,52-54$ & 4.12 & 0.33 & 1.94 & 220 & 41 & 93 & 73 & 25 & 47 & 46 & 19 \\
\hline $39-2,100-102$ & 4.75 & 0.31 & 1.70 & 300 & 35 & 91 & 39 & 16 & 39 & 45 & 64 \\
\hline $41-2,121-123$ & 4.97 & 0.32 & 1.71 & 247 & 25 & 88 & 29 & 10 & 39 & 51 & 39 \\
\hline $43-2,132-136$ & 6.40 & 0.40 & 2.68 & 327 & 1 & 99 & 53 & 24 & 58 & 57 & 16 \\
\hline $45-2,70-74$ & 5.46 & 0.36 & 1.96 & 287 & 28 & 85 & 43 & 16 & 60 & 54 & 24 \\
\hline $47-2,72-76$ & 5.87 & 0.37 & 1.68 & 329 & 31 & 84 & 46 & 18 & 43 & 56 & 19 \\
\hline $49-2,80-82$ & 6.10 & 0.39 & 1.98 & 349 & 36 & 102 & 51 & 14 & 41 & 67 & 41 \\
\hline $51-2,27-29$ & 7.70 & 0.43 & 2.38 & 446 & 34 & 104 & 57 & 25 & 49 & 79 & 31 \\
\hline $53-1,116-120$ & 5.78 & 0.35 & 2.13 & 268 & 38 & 101 & 44 & 12 & 37 & 60 & 30 \\
\hline $55-2,50-52$ & 5.01 & 0.32 & 2.05 & 237 & 36 & 89 & 27 & 9 & 35 & 64 & 31 \\
\hline $57-2,20-24$ & 6.13 & 0.39 & 1.88 & 295 & 41 & 106 & 49 & 20 & 38 & 88 & 21 \\
\hline $59-2,74-78$ & 6.49 & 0.37 & 1.68 & 300 & 30 & 103 & 33 & 15 & 39 & 99 & 45 \\
\hline $63-1,42-44$ & 4.92 & 0.34 & 1.67 & 338 & 28 & 105 & 41 & 11 & 38 & 83 & 57 \\
\hline $65-1,77-79$ & 4.78 & 0.30 & 1.60 & 241 & 50 & 96 & 52 & 11 & 27 & 88 & 17 \\
\hline $70-2,64-67$ & 6.84 & 0.38 & 2.56 & 292 & 58 & 150 & 58 & 23 & 35 & 80 & 15 \\
\hline $71-2,121-125$ & 4.62 & 0.31 & 1.75 & 264 & 45 & 112 & 64 & 8 & 32 & 61 & 10 \\
\hline $73-2,67-68$ & 5.88 & 0.41 & 1.76 & 267 & 48 & 133 & 56 & 16 & 49 & 71 & 22 \\
\hline $85-2,72-74$ & 6.38 & 0.39 & 2.01 & 283 & 41 & 119 & 49 & 13 & 35 & 83 & 26 \\
\hline \multicolumn{12}{|l|}{ Hole 438B } \\
\hline $6-2,121-125$ & 5.34 & 0.36 & 2.34 & 329 & 45 & 145 & 40 & 19 & 37 & 87 & 49 \\
\hline $7-2,98-102$ & 6.48 & 0.44 & 2.74 & 388 & 35 & 107 & 48 & 26 & 45 & 71 & 20 \\
\hline $9-2,100-102$ & 8.02 & 0.53 & 2.97 & 611 & 33 & 110 & 49 & 38 & 36 & 62 & 52 \\
\hline $11-2,59-66$ & 7.19 & 0.54 & 2.59 & 458 & 35 & 96 & 46 & 29 & 59 & 69 & 44 \\
\hline $12-3,128-130$ & 7.20 & 0.46 & 2.05 & 369 & 21 & 86 & 41 & 21 & 53 & 78 & 51 \\
\hline $13-2,78-80$ & 7.00 & 0.40 & 1.68 & 300 & 23 & 80 & 42 & 23 & 42 & 84 & 67 \\
\hline $15-1,57-58$ & 7.05 & 0.52 & 2.72 & 414 & 29 & 104 & 52 & 25 & 50 & 103 & 43 \\
\hline $17-2,61-65$ & 7.62 & 0.57 & 2.69 & 359 & 21 & 93 & 90 & 25 & 126 & 109 & 64 \\
\hline $19-2,28-32$ & 6.01 & 0.44 & 4.52 & 313 & 12 & 81 & 61 & 16 & 129 & 63 & 48 \\
\hline $21-2,75-78$ & 7.65 & 0.43 & 2.43 & 234 & 56 & 64 & 64 & 25 & 49 & 79 & 34 \\
\hline $23-2,104-105$ & 7.54 & 0.52 & 2.55 & 277 & 26 & 84 & 84 & 22 & 65 & 66 & 61 \\
\hline \multicolumn{12}{|l|}{ Hole 439} \\
\hline $7-2,90-93$ & 7.55 & 0.46 & 2.91 & 352 & 49 & 108 & 52 & 20 & 43 & 86 & 42 \\
\hline $9-2,16-19$ & 5.68 & 0.36 & 2.28 & 349 & 50 & 145 & 63 & 16 & 50 & 78 & 46 \\
\hline $11-2,29-32$ & 7.89 & 0.54 & 3.07 & 660 & 36 & 110 & 50 & 28 & 50 & 61 & 37 \\
\hline $13-1,86-88$ & 8.55 & 0.50 & 2.44 & 323 & 15 & 78 & 59 & 31 & 71 & 90 & 23 \\
\hline $15-2,105-107$ & 7.80 & 0.49 & 2.21 & 307 & 17 & 81 & 55 & 24 & 62 & 68 & 20 \\
\hline $17-3,28-31$ & 7.36 & 0.50 & 2.36 & & 10 & 73 & 44 & 20 & 48 & 91 & 23 \\
\hline $19-1,57-58$ & 7.46 & 0.42 & 2.43 & 371 & 12 & 67 & 41 & 14 & 61 & 92 & 17 \\
\hline $21-2,68-70$ & 6.24 & 0.43 & 2.35 & 314 & 12 & 74 & 48 & 9 & 79 & 95 & 39 \\
\hline
\end{tabular}


TABLE 1 - Continued

\begin{tabular}{|c|c|c|c|c|c|c|c|c|c|c|c|}
\hline $\begin{array}{c}\text { Sample } \\
\text { (Interval in } \mathrm{cm} \text { ) }\end{array}$ & $\underset{(\%)}{\mathrm{Al}}$ & $\begin{array}{c}\mathrm{Ti} \\
(\%)\end{array}$ & $\begin{array}{r}\mathrm{Fe} \\
(\%)\end{array}$ & $\underset{(\mathrm{ppm})}{\mathrm{Mn}}$ & $\underset{(\mathrm{ppm})}{\mathrm{Cu}}$ & $\underset{(\mathrm{ppm})}{\mathrm{Zn}}$ & $\begin{array}{c}\mathrm{Ni} \\
(\mathrm{ppm})\end{array}$ & $\begin{array}{c}\mathrm{Co} \\
(\mathrm{ppm})\end{array}$ & $\underset{(\mathrm{ppm})}{\mathrm{Cr}}$ & $\begin{array}{c}\mathrm{Li} \\
(\mathrm{ppm})\end{array}$ & $\begin{array}{c}\mathrm{Sr} \\
(\mathrm{ppm})\end{array}$ \\
\hline \multicolumn{12}{|l|}{ Hole 439} \\
\hline $23-2,17-19$ & 7.99 & 0.41 & 1.90 & 262 & 10 & 63 & 42 & 25 & 38 & 83 & 17 \\
\hline $25-1,78-81$ & 7.91 & 0.43 & 1.56 & 361 & 18 & 63 & 44 & 29 & 40 & 56 & 53 \\
\hline $27-1,99-101$ & 7.96 & 0.32 & 1.82 & 275 & 7 & 64 & 37 & 34 & 25 & 55 & 51 \\
\hline $29-1,114-119$ & 8.43 & 0.34 & 1.94 & 324 & 11 & 45 & 44 & 31 & 20 & 62 & 50 \\
\hline $31-2,86-88$ & 6.48 & 0.34 & 1.75 & 678 & 7 & 52 & 37 & 19 & 25 & 47 & 75 \\
\hline \multicolumn{12}{|l|}{ Hole 440} \\
\hline $1-2,53-57$ & 7.83 & 0.46 & 2.43 & 429 & 37 & 84 & 40 & 32 & 74 & 37 & 84 \\
\hline $3-1,86-90$ & 7.10 & 0.44 & 2.26 & 485 & 53 & 94 & 54 & 27 & 55 & 34 & 31 \\
\hline $5-1,70-74$ & 6.95 & 0.43 & 2.36 & 519 & 50 & 97 & 50 & 20 & 58 & 35 & 48 \\
\hline $7-1,135-139$ & 7.18 & 0.52 & 2.59 & 457 & 61 & 95 & 51 & 26 & 67 & 41 & 20 \\
\hline \multicolumn{12}{|l|}{ Hole $440 \mathrm{~A}$} \\
\hline $3-1,16-20$ & 6.77 & 0.49 & 2.72 & 493 & 39 & 88 & 47 & 15 & 74 & 39 & 52 \\
\hline $5-3,114-118$ & 8.00 & 0.50 & 2.26 & 488 & 58 & 102 & 47 & 26 & 63 & 40 & 14 \\
\hline $7-1,48-52$ & 6.49 & 0.44 & 2.46 & 458 & 46 & 91 & 44 & 16 & 58 & 44 & 47 \\
\hline \multicolumn{12}{|l|}{ Hole $440 \mathrm{~B}$} \\
\hline $1-1,94-98$ & 7.27 & 0.39 & 1.95 & 366 & 68 & 96 & 41 & 20 & 57 & 31 & 32 \\
\hline $3-1,120-124$ & 7.34 & 0.43 & 1.88 & 381 & 42 & 85 & 50 & 18 & 47 & 37 & 24 \\
\hline $5-1,106-110$ & 7.67 & 0.45 & 2.79 & 663 & 35 & 91 & 50 & 22 & 34 & 36 & 19 \\
\hline $7-1,70-74$ & 7.85 & 0.51 & 3.09 & 371 & 57 & 96 & 58 & 25 & 58 & 49 & 18 \\
\hline $9-1,133-137$ & 6.86 & 0.43 & 2.89 & 457 & 55 & 98 & 53 & 18 & 41 & 37 & 30 \\
\hline $11-1,24-28$ & 7.31 & 0.43 & 2.12 & 422 & 71 & 109 & 56 & 23 & 41 & 35 & 25 \\
\hline $13-1,144-148$ & 8.04 & 0.48 & 1.77 & 391 & 62 & 97 & 57 & 26 & 47 & 44 & 12 \\
\hline $15-1,24-26$ & 6.78 & 0.44 & 2.99 & 425 & 81 & 107 & 56 & 11 & 55 & 38 & 33 \\
\hline $17-1,33-38$ & 6.75 & 0.43 & 2.47 & 2095 & 69 & 118 & 66 & 23 & 35 & 35 & 31 \\
\hline $19-1,138-142$ & 6.22 & 0.38 & 2.71 & 506 & 63 & 113 & 53 & 21 & 34 & 30 & 34 \\
\hline $21-1,48-52$ & 6.07 & 0.37 & 2.05 & 890 & 33 & 91 & 46 & 16 & 18 & 22 & 66 \\
\hline $23-1,110-114$ & 6.66 & 0.38 & 2.69 & 1237 & 67 & 118 & 58 & 29 & 34 & 38 & 51 \\
\hline $25-1,26-30$ & 5.57 & 0.42 & 2.45 & 503 & 82 & 99 & 48 & 20 & 40 & 41 & 26 \\
\hline $27-1,120-122$ & 4.20 & 0.31 & 1.83 & 391 & 53 & 82 & 43 & 3 & 21 & 25 & 34 \\
\hline $29-1,20-22$ & 5.05 & 0.39 & 1.91 & 352 & 54 & 88 & 38 & 8 & 33 & 41 & 43 \\
\hline $31-1,124-128$ & 3.77 & 0.31 & 1.74 & 263 & 53 & 69 & 36 & 13 & 33 & 30 & 14 \\
\hline $33-1,131-135$ & 5.02 & 0.35 & 1.51 & 344 & 50 & 80 & 41 & 17 & 40 & 37 & 19 \\
\hline $35-1,114-117$ & 5.08 & 0.25 & 1.30 & 361 & 42 & 70 & 30 & 10 & 21 & 28 & 14 \\
\hline $37-1,44-46$ & 4.21 & 0.29 & 2.02 & 298 & 44 & 69 & 43 & 9 & 30 & 25 & 10 \\
\hline $39-1,92-94$ & 3.88 & 0.27 & 1.58 & 230 & 43 & 72 & 52 & 7 & 45 & 25 & 24 \\
\hline $41-1,102-105$ & 4.25 & 0.28 & 1.92 & 207 & 61 & 70 & 49 & 7 & 40 & 26 & 1 \\
\hline $43-1,80-83$ & 4.17 & 0.30 & 2.00 & 309 & 44 & 77 & 49 & 8 & 44 & 29 & 27 \\
\hline $45-1,134-138$ & 5.23 & 0.32 & 2.33 & 288 & 58 & 79 & 42 & 15 & 45 & 33 & 7 \\
\hline $47-1,45-49$ & 4.98 & 0.36 & 2.14 & 317 & 36 & 81 & 55 & 8 & 58 & 32 & 28 \\
\hline $49-1,70-72$ & 3.82 & 0.24 & 1.70 & 252 & 46 & 65 & 37 & 19 & 34 & 25 & 1 \\
\hline $51-1,64-68$ & 5.74 & 0.37 & 2.57 & 503 & 59 & 95 & 52 & 22 & 40 & 37 & 37 \\
\hline $53-1,82-84$ & 5.77 & 0.37 & 2.81 & 979 & 57 & 96 & 51 & 20 & 50 & 40 & 4 \\
\hline $55-1,64-67$ & 6.89 & 0.37 & 2.68 & 426 & 57 & 93 & 49 & 20 & 44 & 35 & 22 \\
\hline $57-1,21-26$ & 6.14 & 0.36 & 2.50 & 301 & 66 & 103 & 41 & 18 & 46 & 42 & 5 \\
\hline $59-1,106-108$ & 5.37 & 0.33 & 2.64 & 401 & 85 & 93 & 69 & 21 & 42 & 36 & 35 \\
\hline $61-1,70-72$ & 6.55 & 0.41 & 3.07 & 410 & 72 & 98 & 63 & 19 & 44 & 44 & 2 \\
\hline $63-1,58-60$ & 3.86 & 0.29 & 2.04 & 362 & 72 & 81 & 53 & 8 & 43 & 36 & 1 \\
\hline $65-1$ & 4.85 & 0.33 & 2.46 & 698 & 61 & 98 & 66 & 16 & 43 & 40 & 4 \\
\hline $67-1,124-126$ & 5.73 & 0.38 & 3.00 & 450 & 58 & 96 & 58 & 18 & 46 & 43 & 4 \\
\hline $69-1,136-139$ & 6.67 & 0.40 & 2.65 & 474 & 60 & 96 & 62 & 15 & 40 & 44 & 19 \\
\hline $71-1,51-54$ & 6.84 & 0.49 & 3.11 & 601 & 68 & 98 & 40 & 23 & 49 & 53 & 8 \\
\hline \multicolumn{12}{|l|}{ Hole 441} \\
\hline $1-2,52-56$ & 7.50 & 0.54 & 2.97 & 828 & 46 & 88 & 25 & 31 & 51 & 32 & 67 \\
\hline $7-1,43-45$ & 5.39 & 0.35 & 2.25 & 613 & 69 & 91 & 52 & 13 & 43 & 34 & 11 \\
\hline $8-1,140-144$ & 5.02 & 0.35 & 1.89 & 417 & 66 & 77 & 50 & 9 & 37 & 30 & 9 \\
\hline \multicolumn{12}{|l|}{ Hole $441 \mathrm{~A}$} \\
\hline $4-4,22-27$ & 6.07 & 0.36 & 2.32 & 390 & 72 & 81 & 58 & 11 & 37 & 35 & 1 \\
\hline $5-1,96-100$ & 7.08 & 0.49 & 3.31 & 557 & 22 & 75 & 46 & 19 & 42 & 42 & 1 \\
\hline $11-1,28-30$ & 7.71 & 0.44 & 2.34 & 1154 & 74 & 107 & 55 & 26 & 30 & 49 & 3 \\
\hline $12-1,130$ & 5.97 & 0.35 & 2.01 & 690 & 66 & 86 & 53 & 14 & 52 & 40 & 5 \\
\hline $13-1,98-102$ & 5.83 & 0.38 & 2.45 & 591 & 67 & 95 & 41 & 22 & 45 & 41 & 5 \\
\hline \multicolumn{12}{|l|}{ Hole 441B } \\
\hline $1-1,27-30$ & 6.61 & 0.36 & 2.14 & 576 & 77 & 85 & 50 & 20 & 43 & 40 & 9 \\
\hline $2-1,89-91$ & 7.83 & 0.40 & 2.73 & 1300 & 87 & 89 & 58 & 36 & 45 & 45 & 1 \\
\hline
\end{tabular}




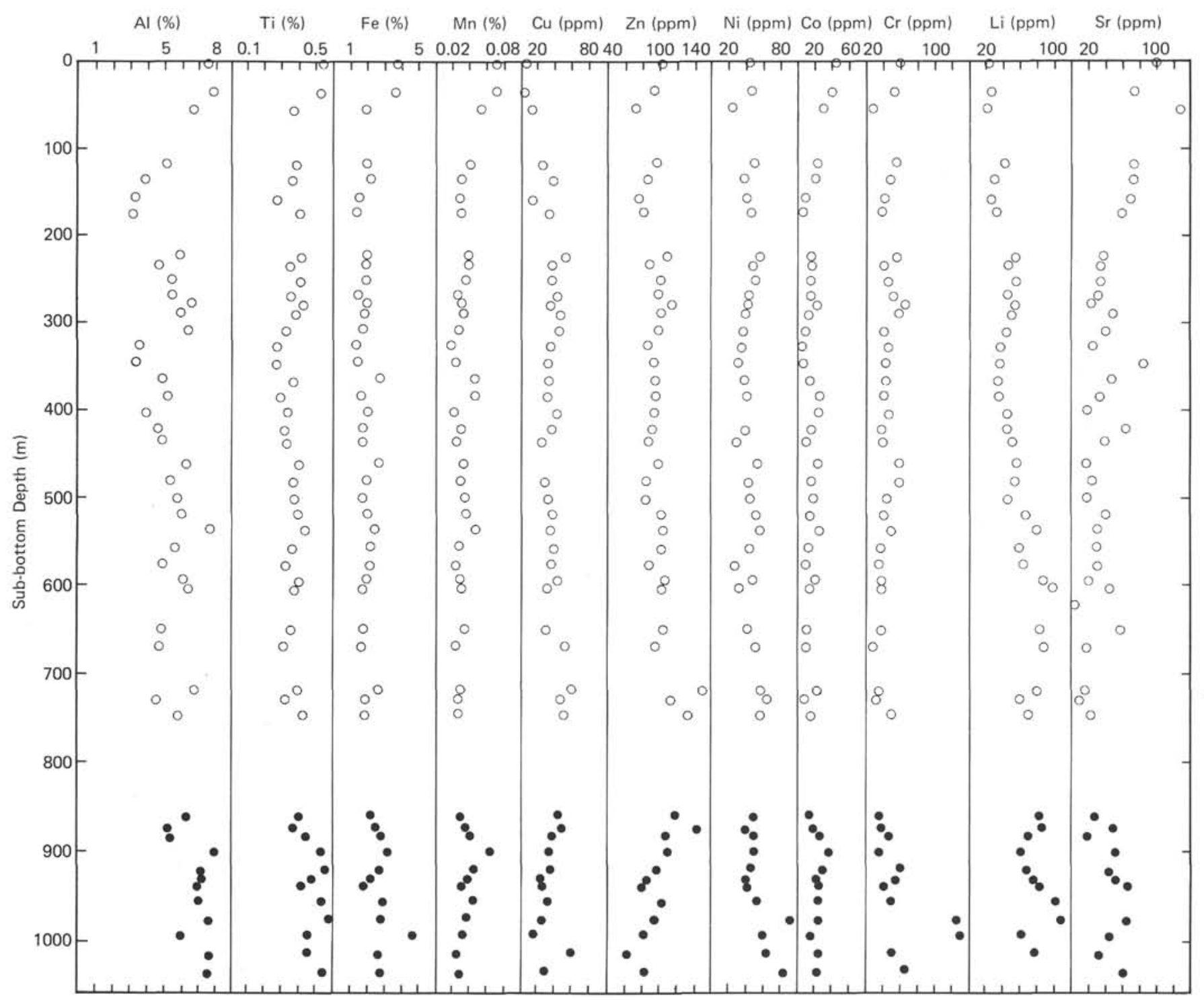

Figure 1. Sediment composition of Site 438, uncorrected for carbonate and salt, versus depth. (Open circle represents Hole 438A sediments; solid circle represents Hole 438B sediments.)

Vertical distribution of $\mathrm{Al}$ and Ti exhibits no particular pattern throughout the core sections, whereas $\mathrm{Fe}$ concentrations show an abrupt change at the boundary between the upper Oligocene and the middle Miocene. $\mathrm{Mn}$ is not correlative to either the lithologic features or the age of sediments, although its higher values occur in both Miocene and the upper Oligocene sediments. $\mathrm{Cu}$ and $\mathrm{Zn}$ tend to decrease slightly toward basement. Co reaches a maximum value in the lower part of the lower Miocene sediments, but this maximum is less than that of other trace elements. Although $\mathrm{Cr}$ concentrations are lower in the upper Oligocene than in the Miocene, there is no vertical variation in abundance. Li concentrations are higher in the Miocene, especially the lower Miocene, than in the upper Oligocene. In contrast, $\mathrm{Sr}$ concentrations are lower in the lower Miocene than in the middle Miocene and upper Oligocene. The elevated $\mathrm{Sr}$ levels in the upper Oligocene may be due mainly to numerous molluscan fragments.
Site 440 (Holes 440, 440A, and 440B)

Three holes (Holes 440, 440A, and 440B) were drilled at Site 440 on the trench inner slope, $28 \mathrm{~km}$ west of the Japan Trench axis. The samples range in age from late Miocene to Holocene. The predominant lithological features are pebbly silt, clayey silt, diatomaceous ooze, diatomaceous claystone, and siltstone containing intervals characterized by mass-movement disturbance of the bedding.

The chemical composition of sediments at Site 440 reflects no lithological characteristics (Figure 2). Al content is higher in the upper Pliocene-Holocene and lower Miocene. The samples between 440 and 600 meters subbottom (lower-upper Pliocene) generally contain less $\mathrm{Al}$ than samples in the upper and in the near-bottom parts of cores. The vertical Ti distribution pattern is similar to that of Al. As is obvious from Figure 2 and Table 2, the vertical profile of $\mathrm{Fe}$ exhibits a significantly uniform 


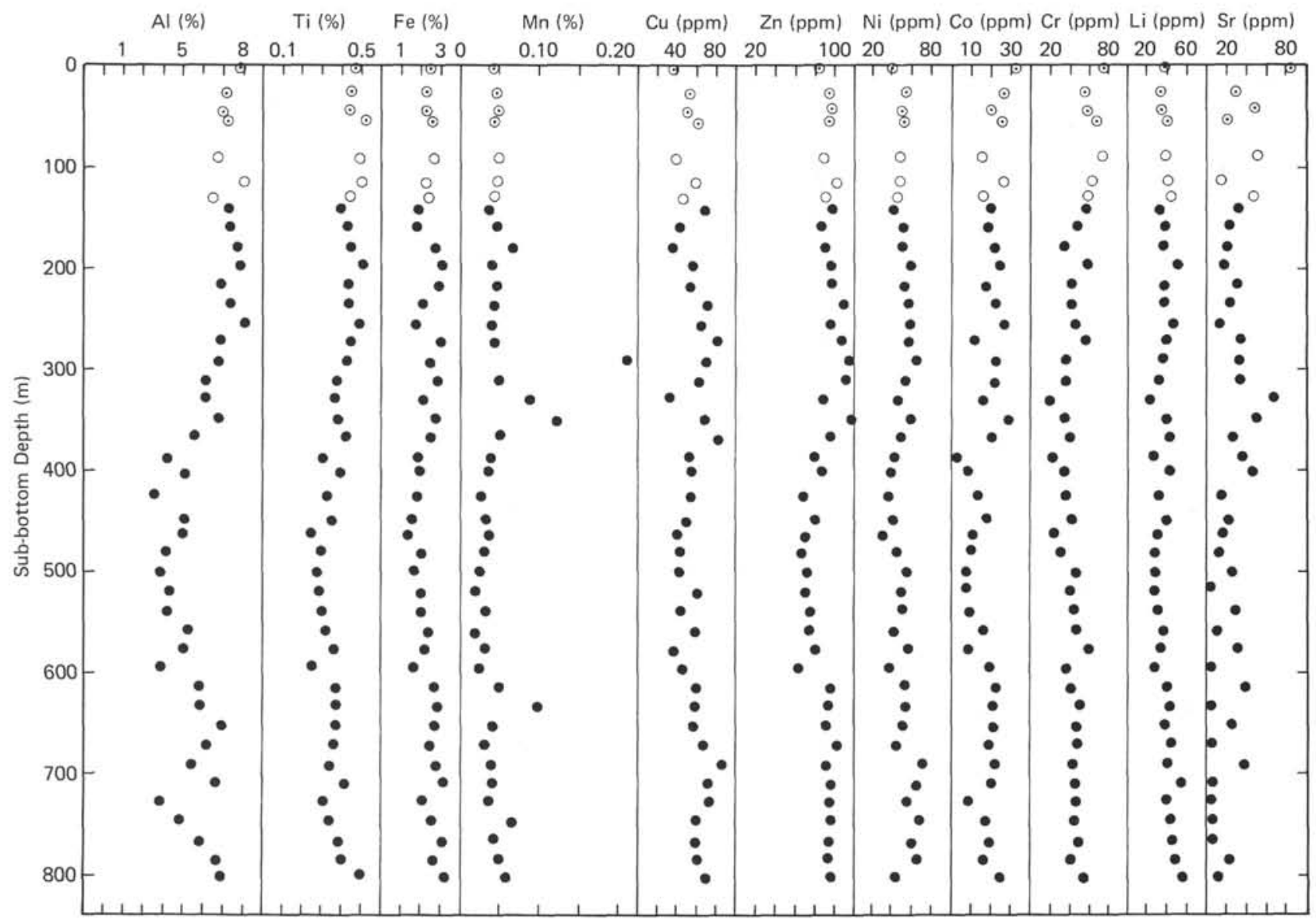

Figure 2. Sediment composition of Site 440, uncorrected for carbonate and salt, versus depth from sediment surface. (Circle with center dot represents Hole 440 sediments; open circle represents Hole $440 \mathrm{~A}$ sediments; solid circle represents Hole $440 B$ sediments.)

distribution. By contrast, $\mathrm{Mn}$ is remarkably variable. However, its elevated values, which occur in the upper Pliocene-lower Pleistocene (290-350 m sub-bottom) and lower Pliocene (630 m sub-bottom), provide no correlation with either lithological natures or geological ages. Furthermore, there are no significant differences in distributions of trace elements throughout the core sections, in spite of a slight increase in $\mathrm{Zn}, \mathrm{Cu}, \mathrm{Co}$, and $\mathrm{Cr}$ near 300 and 600 meters sub-bottom.

\section{Site 441 (Holes 441, 441A, and 441B)}

Site 441 is located downslope from Site 440 at a water depth of 5656 meters. The lithology of cores from Site 441 is very similar to those from Sites 434 (Leg 56) and 440. The composition of sediments at all these sites is hemipelagic clay and silt with variable siliceous biogenic and volcanic components. Geologic age ranges from the lower Miocene to the Holocene. The cores are highly fractured, and consequently core recovery is poor.

Table 2 shows that the amount of major and minor elements in the different sediments is comparable to that of equivalent ages at other sites, except for $\mathrm{Mn}$ and $\mathrm{Sr}$. $\mathrm{Al}, \mathrm{Ti}$, and $\mathrm{Fe}$ are abundant in the upper parts of cores (Pleistocene) compared to the lower zones (lower Pliocene-upper Miocene). Average Mn concentrations in the Pleistocene and upper Miocene are comparable and twice as high as in the lower Pliocene. The remarkably higher concentration of $\mathrm{Sr}$ in the Pleistocene, which is about 10 times as large as in the Pliocene-Miocene, may result in part from the presence of calcareous pebbles or concretions.

The relations between the major elements $\mathrm{Al}, \mathrm{Fe}$, and $\mathrm{Mn}$ are shown in the ternary diagram in Figure 3 . The sediments from Leg 57 are obviously exceptionally poor in $\mathrm{Mn}$. In general, $\mathrm{Al}$-poor and Fe- and $\mathrm{Mn}$-rich deposits have been found on submarine volcanoes (Zelenov, 1964; Bonatti and Joensuu, 1966), active oceanic ridges, or near-basement sediments in contact with basalts (Murray and Renard, 1891; Revelle, 1944; El Wakeel and Riley, 1961; Boström and Peterson, 1969; Boström et al., 1969; Horowitz, 1970, 1974; Cronan et al., 1972; Cronan and Garrett, 1973; Piper, 1973). Such metalliferous sediments have been considered to originate from volcanic processes such as volcanic emanations or hydrothermal leaching of basalt with sea water. Figure 3 demonstrates that the sediments from Leg 57 are apparently different from those in the active oceanic ridge (A in Figure 3), in volcanogenic or low heat flow areas on the active ridge (B), and in metalliferous basal sediments (C). Moreover, sediments from the Japan Trench transect are Al-rich and $\mathrm{Mn}$ - and $\mathrm{Fe}$-poor with respect to those in the present normal pelagic sediments of the 
TABLE 2

Average Chemical Composition of Sediments from Deep Sea Drilling Project Leg 57

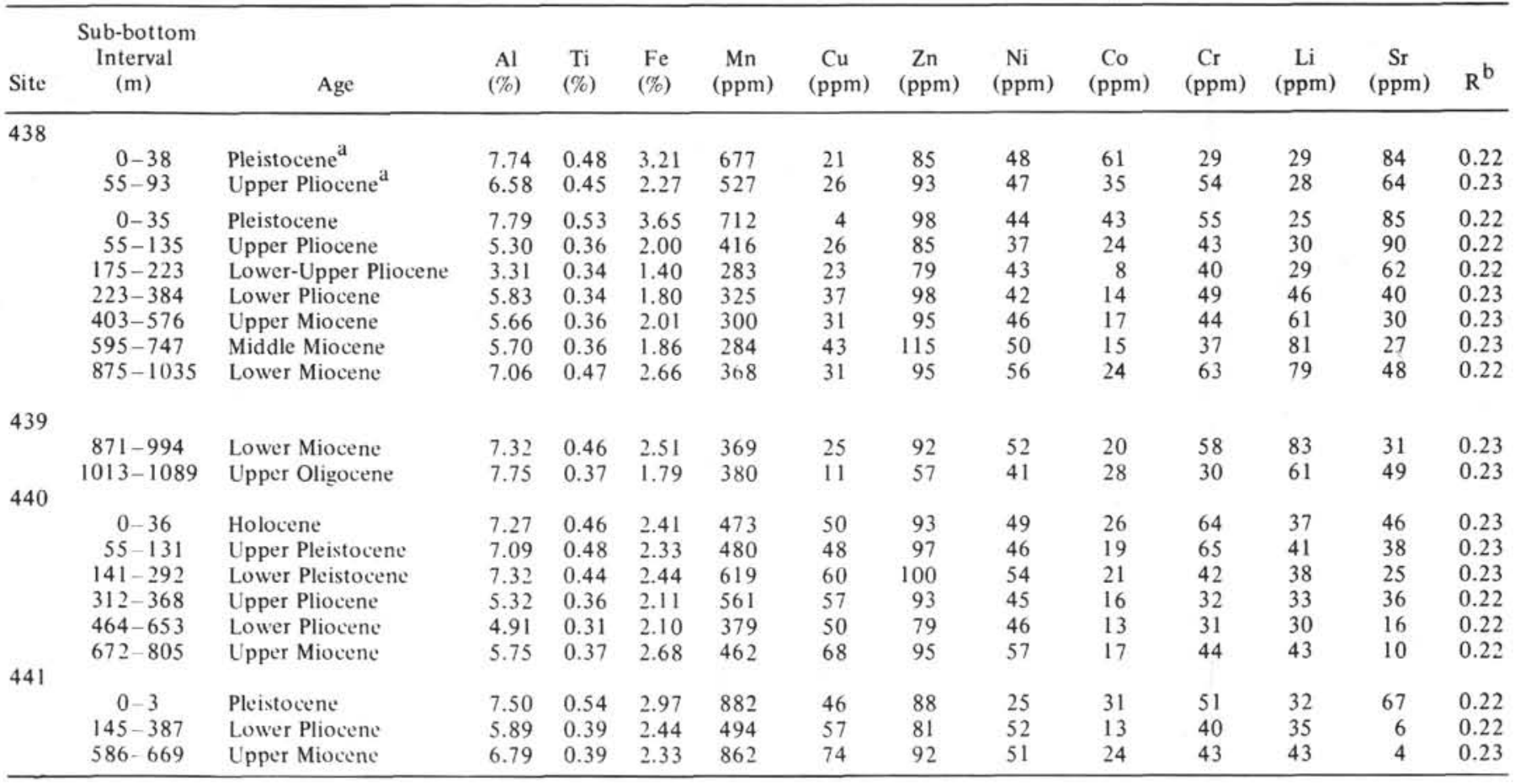

${ }^{a}$ Hole 438.

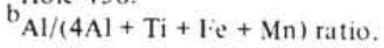

Pacific (D). It is reasonable, therefore, to conclude that the sediments from Leg 57 are mostly of a nonvolcanic, "shallower" water origin, although volcanic ash composes a significant part of the sediment. This conclusion is also supported by the ternary diagram $\mathrm{Zn}-\mathrm{Ni}-\mathrm{Cu}$. It is obvious from Figure 4 that sediments from this area are chemically intermediate between the terrigenous and pelagic sediments.

\section{Modes of Sedimentation}

Examination of the data presented in Tables 1 and 2 and in Figures 1 and 2 indicates a marked difference in the concentrations of the elements through time. $\mathrm{Al}$ and Ti reflect principally the abundance of detrital constituents, whereas $\mathrm{Fe}$ and $\mathrm{Mn}$ are controlled primarily by the abundance of authigenic constituents (Chester and Hughes, 1966, 1967; Krishnaswami, 1976).

In order to compare directly sediments of different ages, it is necessary to remove the diluting effects of biogenic carbonate and silicate, organic matter, and dried sea salt. To accomplish this, the data were normalized following the procedures outlined by Boström et al. (1972). The calculated $\mathrm{Al} /(4 \mathrm{Al}+\mathrm{Ti}+\mathrm{Fe}+\mathrm{Mn})$ ratios should provide a strong indication of the amount of metals tied up in authigenic phases (represented by $\mathrm{Fe}$ and $\mathrm{Mn}$ ) as well as the amount present in detrital constituents (represented by $\mathrm{Al}$ and $\mathrm{Ti}$ ), and should, because of the removal of most of the dilutants normally present in marine sediments, permit the direct comparison of the authigenic constituents of sediments from different locations and of different ages. As the detrital phases increase, the ratio will increase, whereas as the authigenic constituents increase, the ratio will decrease.

As Table 2 demonstrates, the ratios $(0.22-0.23)$ are slightly greater than those for normal Pacific pelagic sediments $(0.20-0.21)$ and significantly differ from the 0.02 to 0.16 ratios for active oceanic ridge sediments cited by Nohara and Yokota (1978). These high ratios suggest that the chemical composition of sediments from Leg 57 are at least partly the result of terrigenous contamination. Furthermore, the Japan Trench transect sediments appear to be fairly uniform geochemically on the basis of the $\mathrm{Al} /(4 \mathrm{Al}+\mathrm{Ti}+\mathrm{Fe}+\mathrm{Mn})$ ratios. This would indicate that both authigenic element deposition and detrital input have been relatively constant in this area since the late Oligocene (about 32 m.y.B.P.), although volcanic materials were sporadically deposited.

\section{Accumulation Rates of Elements}

Table 3 shows the accumulation rates of sediments. These rates are problematic, however. Most serious is the possibility of physiographically induced error: for example topographic change in the ocean floor through slumping, folding, or turbidity may enhance or decrease the accumulation rate. Therefore uncertainty in dating in physical properties of the sediments may produce errors on the order of 10 to 20 per cent.

The accumulation rates at Sites 438 increase significantly from below the lower Pleistocene-uppermost Pliocene, through the Pliocene, until just below the 


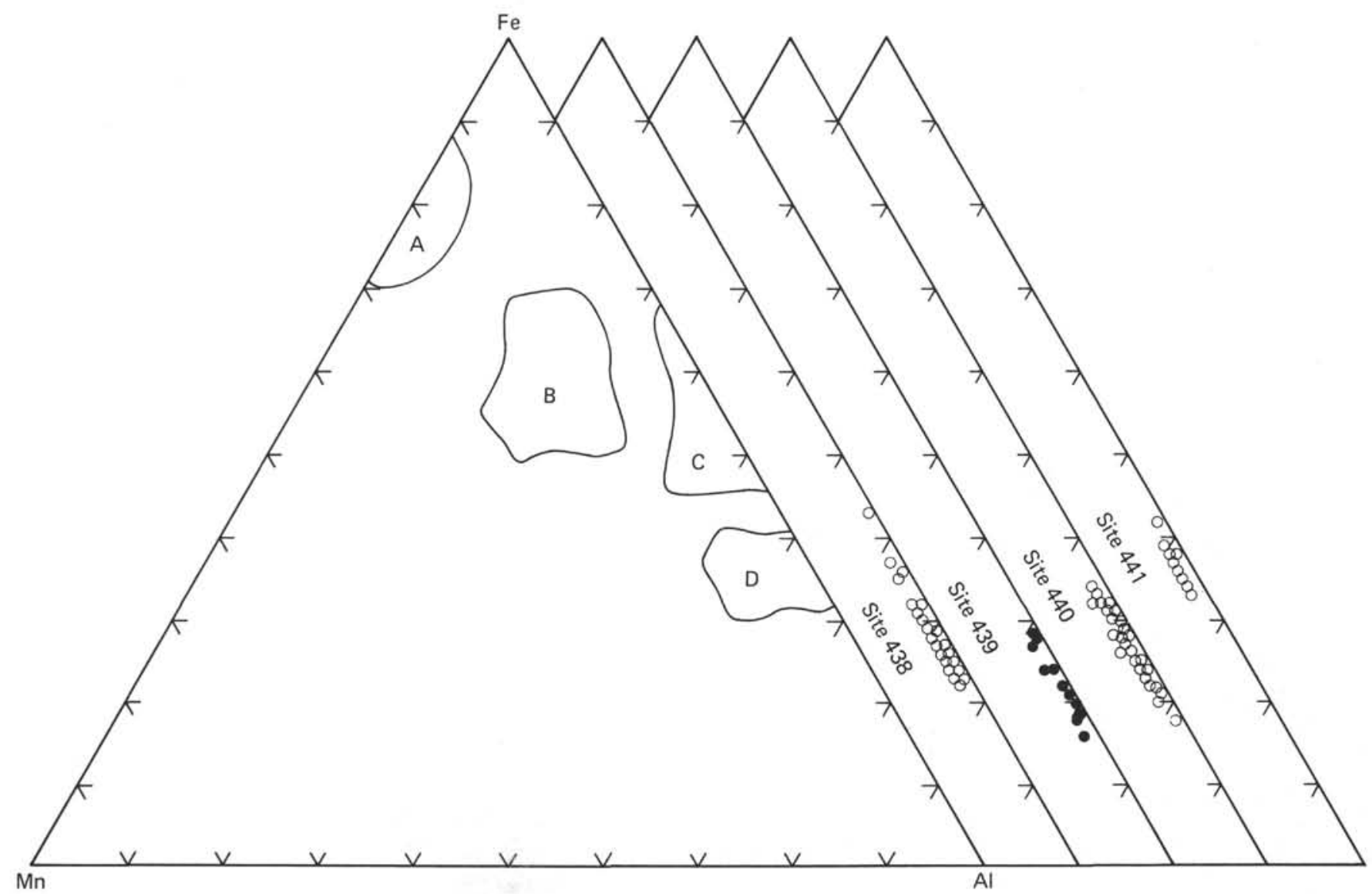

Figure 3. Variations in aluminum, iron, and manganese content in marine sediments. A. High heat flow oceanic ridge sediments (Boström and Peterson, 1969; Boström et al., 1969). B. Low heat flow oceanic ridge or volcanogenic sediments (Goldberg and Arrhenius, 1958; El Wakeel and Riley, 1961; Boström and Peterson, 1969; Boström et al., 1969.) C. Metalliferous basement sediments in contact with volcanic rocks (Horowitz and Cronan, 1976). D. Normal pelagic sediments of the Pacific (Revelle, 1944; Goldberg and Arrhenius, 1958; El Wakeel and Riley, 1961).

Miocene/Pliocene boundary (Table 3). The lower-middle Miocene sediments have slower accumulation rates $\left(8000-9300 \mathrm{mg} / \mathrm{cm}^{2} / 1000 \mathrm{yr}\right.$.). The rate is lowest in the upper Miocene, perhaps because of compaction of the sediments. The core samples (870-1090 m sub-bottom) at Site 439, which are lower Miocene-upper Oligocene, show lower values than samples of equivalent age at other sites.

Sediment accumulation at Site 440 occurs at a very constant rate in the Pliocene and is comparable to that at Site 438. Its Pleistocene section, however, is 200 to 250 meters thicker than at any other site in the Japan Trench transect. The accumulation rates in the Pleistocene are about twice as fast as in the upper Miocene-upper Pliocene. This is probably caused by active downslope sedimentation (see Site 440 Report). According to biostratigraphic data (Site 441 Report), the upper Miocene-lower Pliocene sediments at Site 441 were deposited at a constant rate of $16.8 \mathrm{~cm} / 1000 \mathrm{yr}$., which is slightly faster than deposition in corresponding strata at other sites.

The data in Table 4 were derived from the data in Table 2 and the accumulation rates in Table 3. Accumu- lation rates of elements in trench inner slope sediments are relatively higher in the near-surface sediments than at the bottom. The accumulation rates of $\mathrm{Al}, \mathrm{Ti}, \mathrm{Fe}, \mathrm{Ni}$, and $\mathrm{Cr}$ at Site 438 reach a maximum in the Pliocene sediments in spite of the fact that these elements have maximum concentrations in the lower Miocene. This is probably because sedimentation rate increased by a factor of 2 to 3 in the Pliocene compared with other ages (Table 3). The Pleistocene sections at Site 440 have particularly significant high accumulation rates for metal elements, possibly because of ponding of turbidites (see Site 440 Report). Low metal accumulation rates at Site 439 are attributed mainly to low metal abundances or low sedimentation rates in the upper Oligocene-lower Miocene. In general, metal accumulation rates in the Pliocene at Site 438 are comparable to those at Site 440 except for $\mathrm{Sr}$, whereas the lower Pliocene at Site 441 exhibits high accumulation rates for all elements but $\mathrm{Sr}$. Comparison of metal accumulation rates in the upper Miocene at each site shows a minimum at Site 438 , in which the rate is 3 to 5 times lower than at Sites 440 and 441 . This difference may be attributable either to sedimentation rate or to the geography of ocean floor, because elemental 


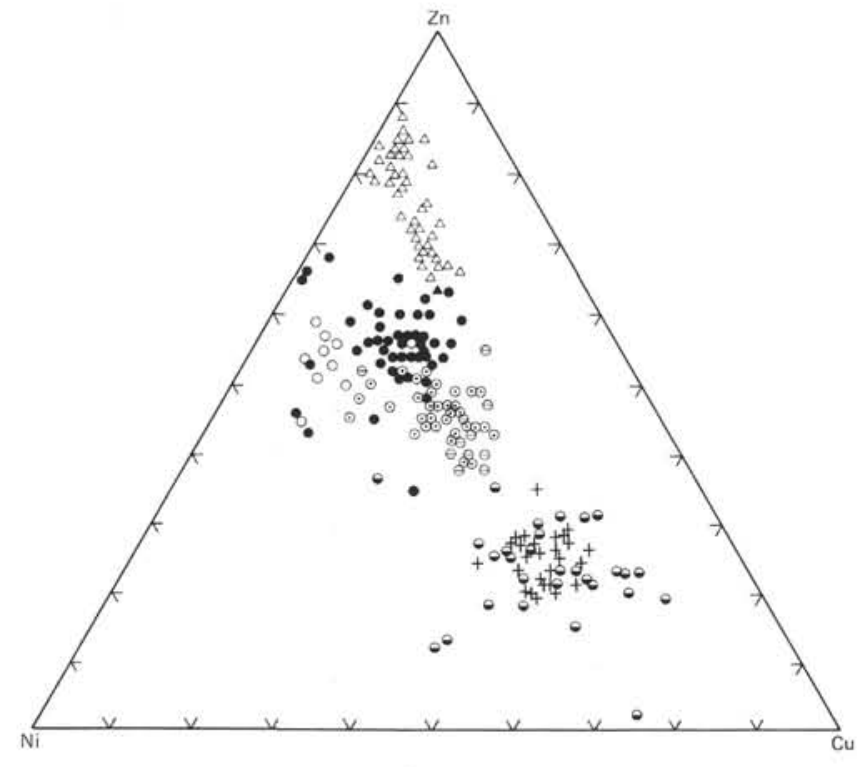

Figure 4. Variations in zinc, nickel, and copper content in marine sediments. $(\triangle=$ shelf sediments off Hachinihe, northeast Japan (Nohara, unpublished data); $\bullet=$ active oceanic ridge sediments; $+=$ normal Pacific pelagic sediments; $\bullet=$ Site 438; $\bigcirc=$ Site 439; $\odot=$ Site 440; $\theta=$ Site 441.)

TABLE 3

Physical Properties and Sedimentation and Accumulation Rates for Sediments from Deep Sea Drilling Project Leg 57

\begin{tabular}{|c|c|c|c|c|}
\hline Site & Age & $\begin{array}{l}\text { Density } \\
\left(\mathrm{g} / \mathrm{cm}^{3}\right)\end{array}$ & $\begin{array}{l}\text { Sedimenta- } \\
\text { tion Rate } \\
\left(\mathrm{cm} / 10^{3} / \mathrm{yr} .\right)\end{array}$ & $\begin{array}{l}\text { Accumulation Rate } \\
\left(\mathrm{mg} / \mathrm{cm}^{2} / 10^{3} / \mathrm{yr}_{\mathrm{r}}\right)\end{array}$ \\
\hline \multicolumn{5}{|l|}{438} \\
\hline & Pleistocene $\mathrm{e}^{\mathrm{a}}$ & 1.7 & 3.0 & 5100 \\
\hline & Upper Pliocene ${ }^{\mathrm{a}}$ & 1.7 & 6.2 & 10540 \\
\hline & Pleistocene & 1.7 & 4.0 & 6800 \\
\hline & Upper Pliocene & 1.5 & 12.0 & 17400 \\
\hline & Lower-Upper Pliocene & 1.4 & 12.0 & 16800 \\
\hline & Lower Pliocene & 1.4 & 12.0 & 16800 \\
\hline & Upper Miocene & 1.4 & 4.0 & 5600 \\
\hline & Middle Miocene & 1.4 & 5.8 & 8120 \\
\hline & Lower Miocene & 1.6 & 5.8 & 9280 \\
\hline \multicolumn{5}{|l|}{439} \\
\hline & Lower Miocene & 1.7 & 1.7 & 2890 \\
\hline & Oligocene & 2.2 & 1.3 & 2860 \\
\hline \multicolumn{5}{|l|}{440} \\
\hline & Holocene & 1.6 & 23.0 & 36800 \\
\hline & Upper Pleistocene & 1.6 & 23.0 & 36800 \\
\hline & Lower Pleistocene & 1.6 & 23.0 & 36800 \\
\hline & Upper Pliocene & 1.6 & 10.0 & 16000 \\
\hline & Lower Pliocene & 1.6 & 10.0 & 16000 \\
\hline & Upper Miocene & 1.7 & 10.0 & 17000 \\
\hline \multicolumn{5}{|l|}{441} \\
\hline & $\begin{array}{l}\text { Lower Pliocene } \\
\text { Upper Miocene }\end{array}$ & $\begin{array}{l}1.7 \\
2.0\end{array}$ & $\begin{array}{l}16.8 \\
16.8\end{array}$ & $\begin{array}{l}28560 \\
33600\end{array}$ \\
\hline
\end{tabular}

${ }^{\mathrm{a}}$ Hole 428 .

abundances except for $\mathrm{Mn}$ and $\mathrm{Cu}$ are of similar orders of magnitude at each site (Table 2).

The accumulation rates of elements in sediments recovered during Leg 57 are about twice as high as those of Leg 56. In addition, high accumulation rates of authigenic constituents such as $\mathrm{Fe}, \mathrm{Mn}$, and others are accompanied by high accumulation of $\mathrm{Al}-\mathrm{Ti}$ detrital phases. This implies that some authigenic phases may have been co-precipitated with detrital phases.

\section{CONCLUSIONS}

Bulk chemical analyses of sediments from the Japan Trench inner slope demonstrates that their chemical composition is similar to those from Sites 434 and 435, Leg 56 (Nohara, this volume). The sediments from both legs are characterized by a greater $\mathrm{Al}$ - and Ti-enrichment and by a depletion of authigenic components especially, $\mathrm{Fe}, \mathrm{Mn}, \mathrm{Cu}$, and $\mathrm{Ni}-$ than in active oceanic ridges and metalliferous basement sediments. This suggests that the island arc - or terrigenous sediments are more important than oceanic ones in forming accretionary wedges. Vertical abundances are slightly variable from one site to another. However, recalculation of the data on a carbonate-, silica-, sea-salt-, and organicmatter-free basis indicates that the nature of detrital input and authigenic element deposition has been relatively constant since the late Oligocene ( 32 m.y.B.P.).

The accumulation rates of Leg 57 elements are high compared to those for Leg 56 and for normal pelagic areas. It has been demonstrated that $\mathrm{Fe}$ and $\mathrm{Mn}$ and other authigenic phases exhibit high accumulation rates in sediments in which there has been a correspondingly high rate of $\mathrm{Al}-\mathrm{Ti}$ detrital deposition. This fact suggests that $\mathrm{Fe}, \mathrm{Mn}$, and other authigenic constituents were deposited at least in part with detrital phases.

\section{ACKNOWLEDGMENTS}

I wish to acknowledge Takashi Fujii, Institute of Geoscience, University of Tsukuba, and Hideo Kagami, Ocean Research Institute, University of Tokyo, for reviewing the manuscript.

\section{REFERENCES}

Bonatti, E., and Joensuu, O., 1966. Deep-sea iron deposits from the South Pacific. Science, 154, 643-645.

Boström, K., Joensuu, O., Valdes, S., and Riera, M., 1972. Geochemical history of South Atlantic Ocean sediments since Late Cretaceous. Mar. Geol., 12, 85-121.

Boström, K., and Peterson, M., 1969. Origin of aluminumpoor sediments in areas of high heat flow on the east Pacific Rise. Mar. Geol., 7, 427-447.

Boström, K., Peterson, M., Joensuu, O., and Fisher, D., 1969. Aluminum-poor ferromanganese sediments on active oceanic ridges. J. Geophys. Res., 74, 3261-3270.

Chester, R., and Hughes, M., 1966. The distribution of manganese, iron and nickel in a North Pacific deep-sea clay core. Deep-Sea Res., 13, 627-634.

, 1967. A chemical technique for the separation of ferromanganese minerals, carbonate minerals and adsorbed trace elements from pelagic sediments. Chem. Geol., 2, 249-262.

Cronan, D., and Garrett, D., 1973. The distribution of elements in metalliferous Pacific sediments collected during the D.S.D.P. Nature Phys. Sci., 242, 88-89.

Cronan, D., van Andel, T., Heath, G., Dinkleman, M., Bennett, R., Bukry, D., Charleston, S., Knapps, A., Rodolfo, K., and Yeats, R., 1972. Iron-rich basel sediments from the eastern equatorial Pacific: Leg XVI, D.S.D.P. Science, $175,61-63$. 
TABLE 4

Average Accumulation Rates for Constituents in Sediments from Deep Sea Drilling Project Leg 57

\begin{tabular}{|c|c|c|c|c|c|c|c|c|c|c|c|c|}
\hline Site & Age & $\begin{array}{c}\mathrm{Al} \\
\text { (in } \mathrm{mg} /\end{array}$ & $\mathrm{m}^{\mathrm{Ti}} / 10$ & $\begin{array}{c}\mathrm{Fe} \\
000 / \mathrm{yr})\end{array}$ & Mn & $\mathrm{Cu}$ & $\begin{array}{l}\mathrm{Zn} \\
\text { (in } \mathrm{mg} / \mathrm{h}\end{array}$ & $\stackrel{\mathrm{Ni}}{\mathrm{m}^{2} / 1,0}$ & $\begin{array}{l}\text { Co } \\
00,000\end{array}$ & $\begin{array}{c}\mathrm{Cr} \\
\mathrm{yr})\end{array}$ & $\mathrm{Li}$ & $\mathrm{Sr}$ \\
\hline \multicolumn{13}{|l|}{438} \\
\hline & Pleistocene $^{\mathrm{a}}$ & 395 & 24 & 164 & 3453 & 107 & 434 & 245 & 311 & 148 & 148 & 428 \\
\hline & Upper Pliocene ${ }^{\mathrm{a}}$ & 694 & 47 & 239 & 5555 & 274 & 980 & 495 & 369 & 569 & 295 & 675 \\
\hline & Pleistocene & 530 & 36 & 248 & 4842 & 27 & 666 & 299 & 292 & 374 & 170 & 578 \\
\hline & Upper Pliocene & 922 & 63 & 348 & 7238 & 452 & 1479 & 644 & 418 & 748 & 522 & 566 \\
\hline & Lower-upper Pliocene & 556 & 57 & 235 & 4757 & 386 & 1327 & 722 & 134 & 672 & 487 & 1042 \\
\hline & Lower Pliocene & 979 & 57 & 302 & 5460 & 622 & 1646 & 706 & 235 & 823 & 773 & 672 \\
\hline & Upper Miocene & 317 & 20 & 113 & 1680 & 174 & 532 & 258 & 95 & 246 & 342 & 168 \\
\hline & Middle Miocene & 463 & 29 & 151 & 2307 & 349 & 934 & 406 & 122 & 300 & 658 & 219 \\
\hline & Lower Miocene & 655 & 44 & 247 & 3415 & 288 & 882 & 520 & 223 & 585 & 733 & 446 \\
\hline 439 & Lower Miocene & 212 & & 73 & 1066 & 72 & & & & & & \\
\hline & Upper Oligocene & 222 & 11 & 52 & 1087 & 31 & $\begin{array}{l}200 \\
163\end{array}$ & 13 & $\begin{array}{l}58 \\
80\end{array}$ & $\begin{array}{r}108 \\
86\end{array}$ & 24 & 90 \\
\hline \multicolumn{13}{|c|}{ 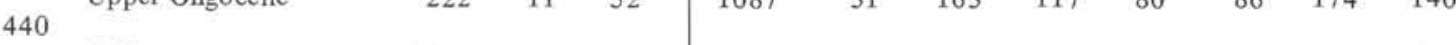 } \\
\hline & Holocene & 2675 & 169 & 887 & 17406 & 1840 & 3422 & 1803 & 957 & 2355 & 1362 & 1693 \\
\hline & Upper Pleistocene & 2609 & 177 & 857 & 17664 & 1766 & 3570 & 1692 & 699 & 2392 & 1509 & 1398 \\
\hline & Lower Pleistocene & 2693 & 169 & 898 & 22779 & 2208 & 3680 & 1987 & 773 & 1546 & 1398 & 920 \\
\hline & Upper Pliocene & 851 & 58 & 338 & 8976 & 912 & 1488 & 720 & 256 & 512 & 528 & 576 \\
\hline & Lower Pliocene & 786 & 50 & 336 & 6064 & 800 & 1264 & 736 & 208 & 656 & 480 & 256 \\
\hline & \multicolumn{12}{|l|}{ Upper Miocene } \\
\hline & Lower Pliocene & 1682 & 111 & 679 & 14109 & 1628 & 2313 & 1485 & 371 & 1142 & 1000 & 171 \\
\hline & Upper Miocene & 2281 & 131 & 783 & 28963 & 2486 & 3091 & 1714 & 806 & 1445 & 1445 & 134 \\
\hline
\end{tabular}

${ }^{\mathrm{a}}$ Hole 438.

El Wakeel, S. K., and Riley, J. P., 1961. Chemical and mineralogical studies of deep-sea sediments. Geochim. Cosmochim. Acta, 25, 110-146.

Goldberg, E. D., and Arrhenius, G. O. S., 1958. Chemistry of Pacific pelagic sediments. Geochim. Cosmochim. Acta, 13, 153-212.

Horowitz, A., 1970. The distribution of $\mathrm{Pb}, \mathrm{Ag}, \mathrm{Sn}, \mathrm{Tl}$ and $\mathrm{Zn}$ in sediments on active oceanic ridges. Mar. Geol., 9, 241259.

1974. The geochemistry of sediments from the northern Reykjanes Ridge and the Iceland-Faroes Ridge. Mar. Geol. 17, 103-122.

Horowitz, A., and Cronan, D., 1976. The geochemistry of basal sediments from the North Atlantic Ocean. Mar. Geol., 20, 205-228.

Krishnaswami, S., 1976. Authigenic transition elements in $\mathrm{Pa}-$ cific pelagic clays. Geochim. Cosmochim. Acta, 40, 425434.
Murray, J., and Renard, A. F., 1891. Deep-sea deposits. Report on the Scientific Results on the Voyage of H. M. S. "Challenger"' (Vol. 5): London (Longmans).

Nohara, M., and Yokota, S., 1978. The geochemistry of trace elements in pelagic sediments from the Central Pacific Basin. J. Geol. Soc. Japan, 84, 165-175.

Piper, D., 1973. Origin of metalliferous sediments from the East Pacific Rise. Earth Planet. Sci. Lett., 19, 75-82.

Revelle, R. R., 1944. Marine bottom samples collected in the Pacific by the "Carnegie" on its seventh cruise: Washington (Carnegie Institute) Publication 556, pp. 1-180.

Turekian, K., 1964. The marine geochemistry of strontium. Geochim. Cosmochim. Acta, 28, 1479-1496.

Zelenov, K. K., 1964. Iron and manganese in exhalations from the submarine volcano, Banu Wuhu (Indonesia). Dokl. Akad. Nauk. S.S.S.R., 155, 1317-1320. (in Russian) 